Portland State University

PDXScholar

1986

\title{
Neutron activation analysis and chemical inference for the identification of Buena Vista ceramics
}

Daniel D. Sullivan

Portland State University

Follow this and additional works at: https://pdxscholar.library.pdx.edu/open_access_etds

Part of the Archaeological Anthropology Commons, and the Ceramic Arts Commons Let us know how access to this document benefits you.

\section{Recommended Citation}

Sullivan, Daniel D., "Neutron activation analysis and chemical inference for the identification of Buena Vista ceramics" (1986). Dissertations and Theses. Paper 3699.

https://doi.org/10.15760/etd.5583

This Thesis is brought to you for free and open access. It has been accepted for inclusion in Dissertations and Theses by an authorized administrator of PDXScholar. Please contact us if we can make this document more accessible: pdxscholar@pdx.edu. 
AN ABSTRACT OF THE THESIS OF Daniel D. Sullivan for the Master of Arts in Anthropology presented May 15, 1986.

Title: Neutron Activation Analysis and Chemical Inference for the Identification of Buena Vista Ceramics.

APPROVED BY THE MEMBERS OF THE THESIS COMMITTEE:

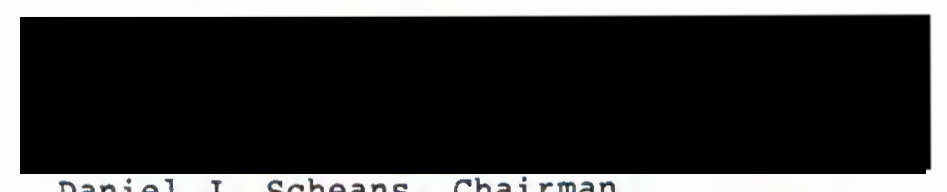

Daniel J. Scheans, Chairman

\section{Ann Bennett}

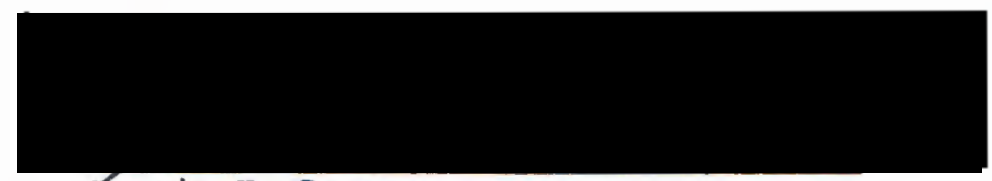

Marvin H. Beeson

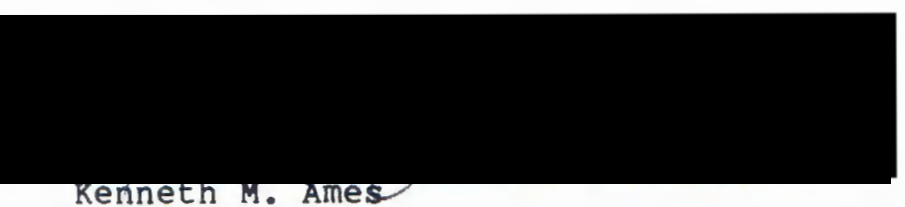

Kenneth \%. Ames 
Instrumental Neutron Activation Analysis was used for this study of stonewares collected from the site of the Buena vista/oregon Pottery Company $(1866-1890)$.

The results show significant chemical signatures in the samples tested. Thorium/ytterbium and thorium/chromium ratios within their respective ranges of variation demonstrate a relative conformity among all samples of Buena Vista ceramics. 
NEUTRON ACTIVATION ANALYSIS AND CHEMICAL INFERENCE FOR THE IDENTIFICATION

OF BUENA VISTA CERAMICS

by

DANIEL D. SULLIVAN

A thesis submitted in partial fulfillment of the requirements for the degree of

\author{
MASTER OF ARTS \\ in \\ ANTHROPOLOGY
}

Portland State University 
TO THE OFFICE OF GRADUATE STUDIES AND RESEARCH:

The members of the Committee approve the thesis of Daniel D. Sullivan presented May 15, 1986.

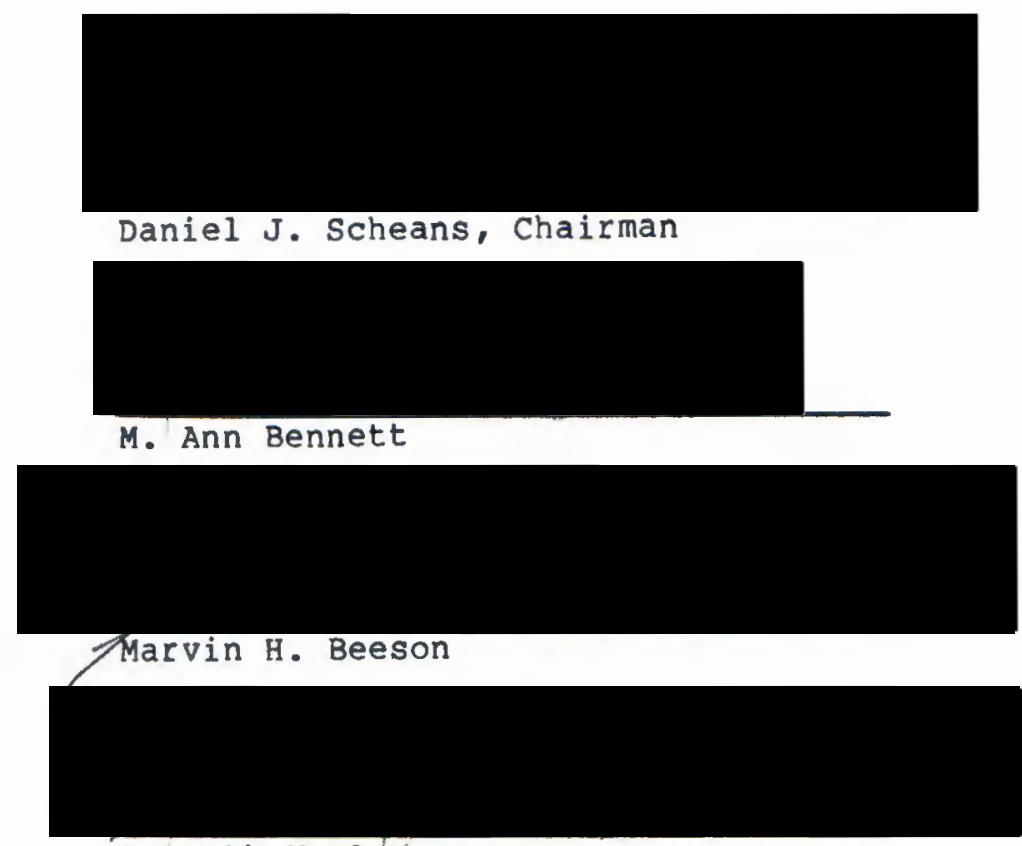

Renneth M. Ames

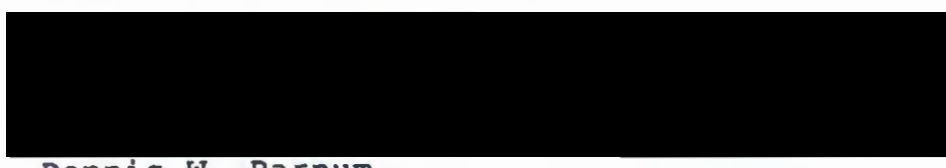

Dennis w. Barnum

APPROVED :

Marc R. Feldesman, Head, Department of Anthropology 


\section{ACKNOWLEDGMENTS}

I am greatly indebted to Daniel scheans, my academic advisor and thesis committee chairman, for his encouragement and guidance throughout this investigation. Without his preliminary study this investigation would not have been possible.

My gratitude goes to Marvin Beeson as a member of my committee and for his generous consultation. Without the technical facilities made available by him, the analysis in this investigation could not have been completed.

I would like to thank Ann Bennett for serving on my committee and especially for her editorial assistance.

I wish to express my appreciation to Kenneth Ames and Dennis Barnum for serving on my committee and for their constructive discussion.

A special thanks to Michael Pollock for the knowledge and advice he shared with me. Without his assistance I could not have performed the specialized tasks required for Instrumental Neutron Activation Analysis. 
TABLE OF CONTENTS

PAGE

ACKNOWLEDGMENTS..............................

LIST OF TABLES.............................. v

LIST OF FIGURES $\ldots \ldots \ldots \ldots \ldots \ldots \ldots \ldots \ldots \ldots \ldots \ldots \ldots \ldots \ldots \ldots \ldots$ vi

\section{CHAPTER}

I INTRODUCTION..........................

Quantification.......................... 2

History $\ldots \ldots \ldots \ldots \ldots \ldots \ldots \ldots \ldots \ldots \ldots \ldots \ldots \ldots \ldots \ldots$

I I EXPERIMENTAL PROCEDURE...................... 4

samples............................. 4

Preparation.......................... 4

Irradiation and Assay.................... 6

Selection of Elements.................... 8

III RESULTS.............................. 10

IV DISCUSSION............................. 15

$\mathrm{Th} / \mathrm{Yb}$ and $\mathrm{Th} / \mathrm{Cr}$ Ratios....................... 15

Chemical variability.................... 15

v ConcLusions............................. 19

REFERENCES CITED............................... 21

APPENDIX.................................... 22 


\section{LIST OF TABLES}

TABLE

PAGE

I Buena Vista and Palouse Pottery Company Neutron

Activation Analysis Samples..................

I Characteristics of Selected Elements in Buena Vista and Palouse ceramics......................

II Mean Element Concentrations in Ceramic Samples......... II 


\section{LIST OF FIGURES}

1. Scattergram of $\mathrm{Th} / \mathrm{Yb}$ Ratios for Buena Vista and

Palouse Ceramics Samples.....................

2. Scattergram of $\mathrm{Th} / \mathrm{Cr}$ Ratios for Buena Vista and

Palouse Ceramic Samples.

3. Comparison of the concentration Ranges of selected 


\section{CHAPTER I}

\section{INTRODUCTION}

The principle objective of this study is to determine the existence of chemical conformities in the clay(s) used for the manufacture of Buena Vista ceramics that may differ from those in similar ceramics from the same historic period. Buena Vista ceramics have been described in a preliminary study by Scheans (1984). His study is focused on stylistic and technological attributes found in ceramic sherds which were surface collected and excavated from a waster dump at the site of the Buena Vista/oregon Pottery Company and compared to whole pieces from private collections. Scheans' analysis has established a typology for and characterized the process of manufacture of Buena Vista stonewares. Differences in style and technology have raised questions about the continuity of the material used for production of these ceramics both in time and location. Therefore, underlying this study is the need to improve the precision of inference and, thereby, future historical, archaeological, and anthropological interpretations of Buena Vista ceramics and others unique to the historical cultural development of the Pacific Northwest.

Clay, being a material specific to its geological origins and various weathering processes, is a configuration of recognizable proportions of chemical elements and conditions leading to deposition. Given a relatively uniform environment for manufacture (e.g., kiln 
temperature, addition of temper, etc.), the products of a specific pottery (e.g., the Buena Vista Pottery Company) should reflect a chemical composition for the most part unchanged from that of the clay(s) used in the process. Using appropriate analytical methods permits (1) the determination of any conformity among samples and, (2) validation of the clay source(s) and its associated manufacturing provenience. Instrumental Neutron Activation Analysis (INAA) is a method for quantitative elemental analysis. The data derived from INAA can produce meaningful results not only on its own merits, but also (1) enhance the credibility of inferences made through other types of analysis and, raise further research objectives.

Chemical compositional studies are in flux and mistakes are being made, but instrumetnal analytical techniques are sensitive, statistical methods are powerful, and effective characterization of pottery is more than a gleam in the eye of the analyst. In evaluating this approach, we especially note the potential of workshop debris (kiln wasters) in establishing local reference groups... As in much archaeolgoical research, ceramic compositional analysis takes place the interface of the natural environment with the social and cultural components of production. With modest improvement in our present body of methods and more judicious use of available techniques, we should soon be able to examine nuances of these relationships (Bishop, Rands and Holley $1982: 318,320)$.

\section{QUANTIFICATION}

Beyond statistical methods embedded in the computer programs required for the derivation of data in this study, elaborate statistical presentations will not be made. Rather, derived data will be displayed in tabular form, and data with inferential merit will be displayed graphically and in bivariate plots. Samples used in this study are not representative of a statistical population. Rather, they were selected 
for INAA on the basis of attributes illustrating a transect of style and technology found in diagnostic sherds from Scheans' (1984) study assemblage. Two questions are considered here: (1) Are any of the variations in style and technology in the assemblage the result of intrusive ceramics? and/or, (2) Are any variations in style and technology in the assemblage a record of historical development at the site?

\section{HISTORY}

The site of the Buena Vista Pottery Company is located in Polk County, Oregon, just south of the town of Independence and a short distance from the left bank of the Willamette River. The pottery produced stonewares between 1866 and 1890 under the proprietorship of Freeman Smith and his son Amedee. The name was changed to the oregon Pottery Company in 1888 (Scheans 1984:50). Archaeology students and volunteers made surface collections and one excavation at the site between 1981 and 1983. Diagnostic ceramic sherds were classified and catalogued at the Ceramic Analysis Laboratory at Portland state University where they are currently curated. Although the pottery produced a variety of products, this study is restricted to the three classes of vessels described by scheans. These include slip glazed, salt glazed, and unglazed wares. Any taxonomic reference in the current study is consistent with the paradigms established within these classes. 
CHAPTER II

EXPERIMENTAL PROCEDURE

\section{SAMPLES}

A total of 32 samples were used for INAA in this study. Twentyseven of these samples were obtained from surface collections and one excavation at the Buena Vista site and selected from Scheans' (1984) study assemblage. The remaining five samples were from sherds known to be products of the Palouse Pottery Company, washington, and selected from the Ceramic Analysis Laboratory collection at Portland state University. The Palouse samples represent the control group in this analysis. A summary of all samples appears in Table $I$.

\section{PREPARATION}

All samples were washed in tap water, dried, and crushed to a coarse powder with a stainless steel mortar and pestle. As indicated in Table I, selected samples were prepared with part of all glaze(s) removed to determine if proportions of elements within the clay bodies of the sherds would be significantly skewed by possibly different element proportions in the glazes. The remaining samples were prepared with glaze intact, or without, as in the case of bisquit wares. Between $0.9515 \mathrm{gm}$ and $1.4679 \mathrm{gm}$ of powder was weighed into $0.5 \mathrm{dram}$ polyethylene sample vials which were then sealed and labeled. 


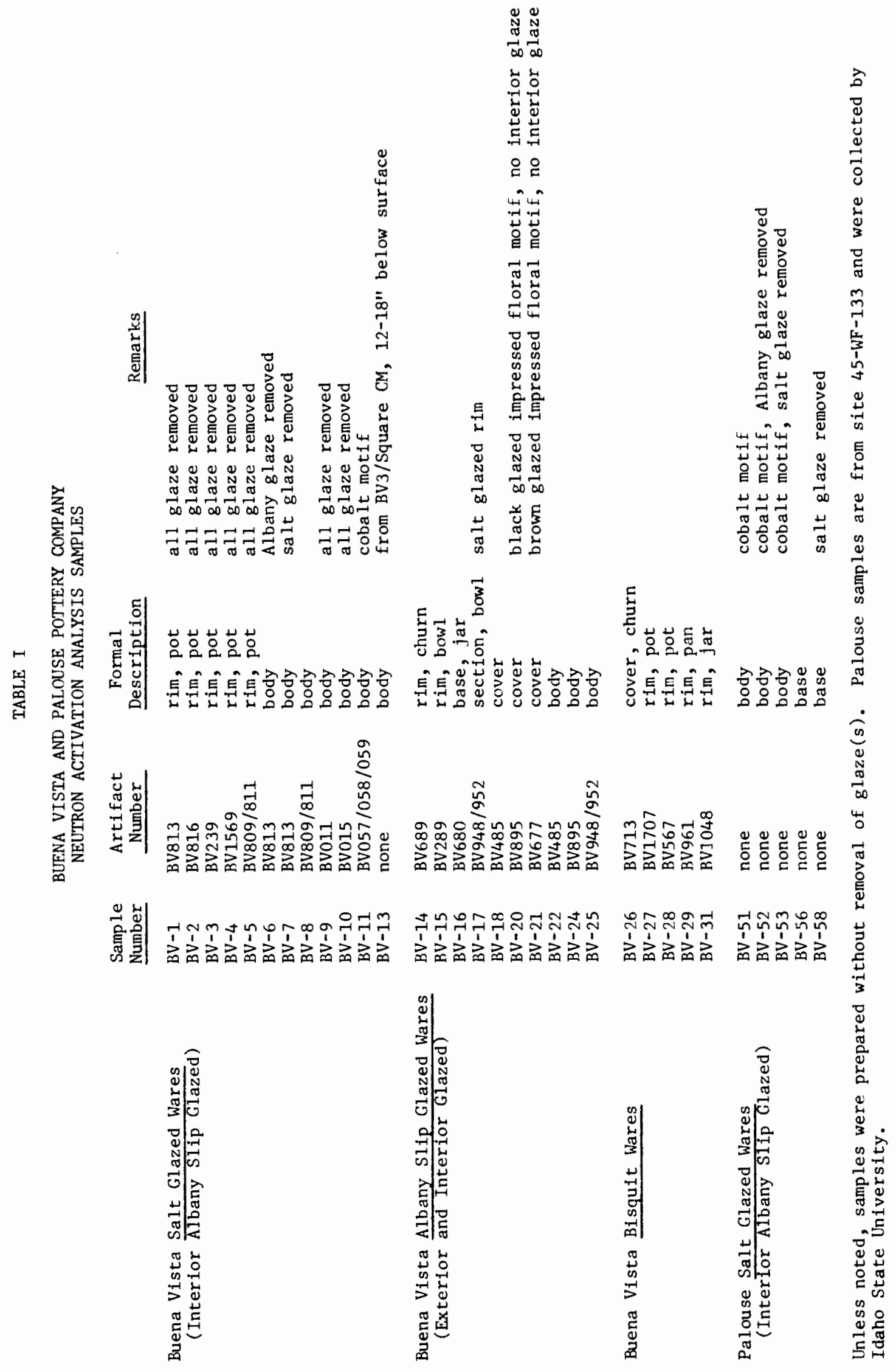




\section{IRRADIATION AND ASSAY}

The sealed vials were irradiated using the TRIGA MARK I, $250 \mathrm{~kW}$ thermal neutron reactor at Reed college in Portland, Oregon. The samples were co-irradiated with a sample of United States Geological Survey (USGS) standard diabase W-1 (Flanagan 1976) as a standard for all elements reported in this study. Exposure was for one hour at $225 \mathrm{~kW}$ with a flux of $1.8 \times 10^{12} \mathrm{n} / \mathrm{cm}^{2} \mathrm{sec}$.

Activities of the irradiated samples were measured using facilities of the Geology Department at Portland State University. Assay of the samples was conducted between four and one-half days and ten days after irradiation using a germanium-lithium high resolution detector coupled to a Tracor Northern 4000-channel pulse height analyzer and a floppy disk data recorder. Detection time was 1,000 seconds for all samples. A description of the neutron activation program and procedures can be found in McMillan (1978).

Data from floppy disks were hard-copied, recompiled, and tabulated according to selected elements and their respective half-lives in days, and gamma ray energies in keV as shown in Table II.

After formatting, all relevant data were then analyzed using a FORTRAN computer program which:

... reduces Instrumental Neutron Activation Analysis data to element abundances by comparing samples to a known concentration in a standard. It also computes relative errors based on counting statistics (Beeson and Reedy 1968).

This program appears in the Appendix. 
TABLE II

CHARACTERISTICS OF SELECTED ELEMENTS

IN BUENA VISTA AND PALOUSE

CERAMICS

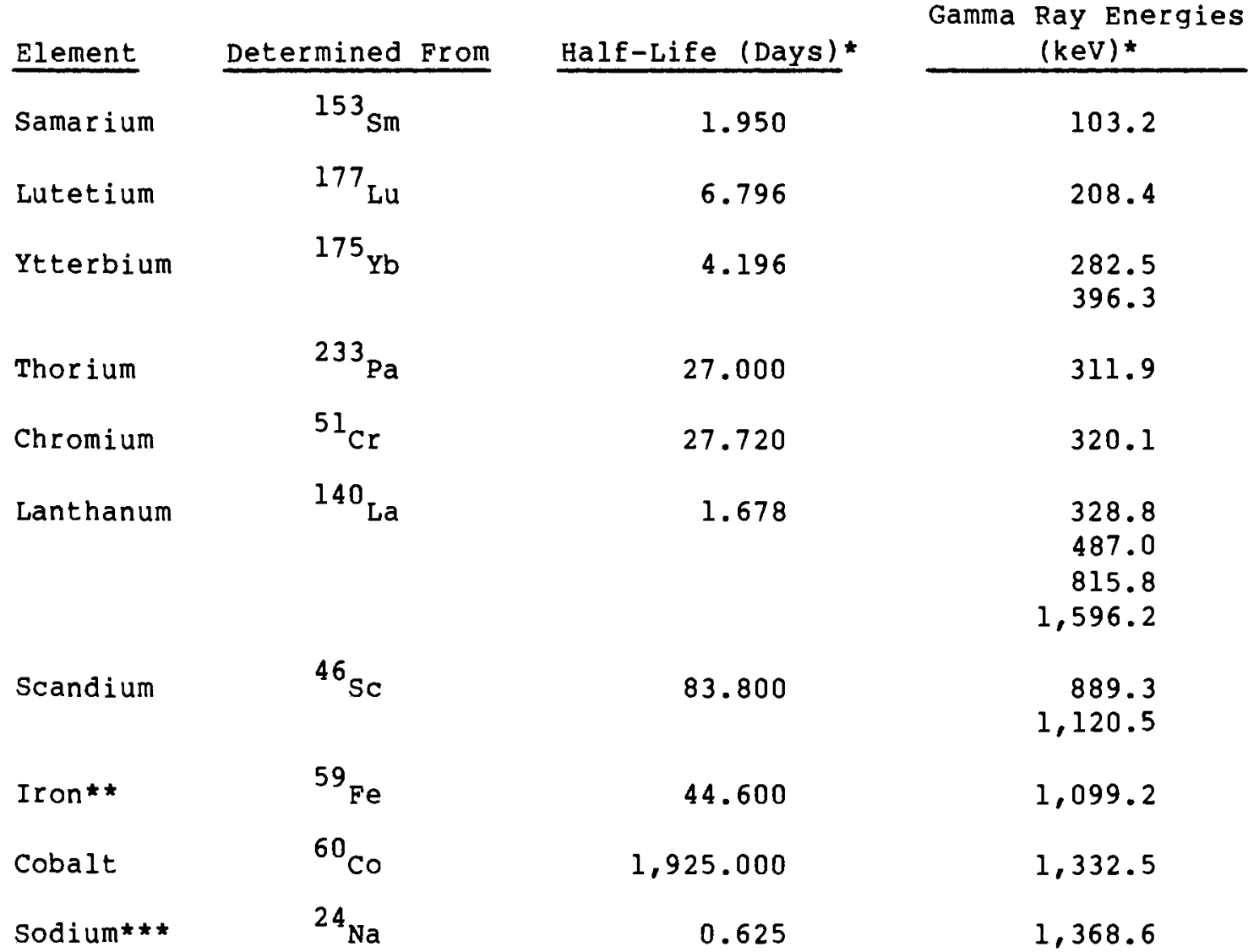

* From McMillan (1978) except for ${ }^{233} \mathrm{~Pa}$ and ${ }^{51} \mathrm{Cr}$, which are from Filby, et al. (1970).

$\star$ Fe as FeO

$\star \star \star$ Na as $\mathrm{Na}_{2} \mathrm{O}$ 
SELECTION OF ELEMENTS

With the exception of cobalt (Co), criteria for selection of elements after analysis was the co-occurrence of the same elements in all samples as prescribed by the standard used for the assay. Cobalt was included, even though it did not fully meet this criteria, because of its occurrence as a colorant in underglazes on some of the samples (see Table I).

Included in the selection process was a consideration of decreases in concentrations of elements in the clay(s) as a function of kiln firing temperatures. Rye (1981:49), reporting on the work of Attas, Yaffe, and Fossey (1977), notes that samarium (Sm), lutetium (Lu), thorium (Th), and chromium (Cr), as well as other elements (which are insignificant to this study), show decreases in concentration after firing. Differences in temperature from one firing to another, and/or a single firing depending on location within the kiln itself could contribute to the overall variability of certain elemental concentrations in clay(s) after firing. Only when sherds are being compared to clay(s) would this be of significance; and then, with temperatures determined to be in excess of $700^{\circ} \mathrm{C}$, correction factors should be applied (1981:49). Stonewares are traditionally fired at kiln temperatures of between approximately $1200^{\circ} \mathrm{C}$ and $1300^{\circ} \mathrm{C}$ (Nelson 1971:141, 311). Since this study compares sherds to sherds (all of which have been technologically identified as stonewares) deviations in the concentrations of the selected elements which are sensitive to firing temperature are, at least in part, relative to kiln temperature firing 
range. Subsequently, these deviations may be reflected as a part of the range of variation in the data. 
CHAPTER III

RESULTS

Results of the analysis for selected elements are presented in Table III. Iron (Fe) and sodium (Na) are reported by convention as oxides. Ferrous oxide (FeO) and sodium oxide $\left(\mathrm{Na}_{2} \mathrm{O}\right)$ may or may not have been resident in the samples from the perspective of INAA (Beeson 1986). It is worth noting, however, that Feo and $\mathrm{Na}_{2} \mathrm{O}$ are commonlyoccurring oxides in ceramic chemistry and are represented for $\mathrm{Fe}$ and $\mathrm{Na}$ in this study as a reference for variability between samples. Feo remains unchanged in the firing process, while $\mathrm{Na}_{2} \mathrm{O}$ is the combustion product of sodium carbonate $\left(\mathrm{Na}_{2} \mathrm{CO}_{3}\right)$ with the loss of carbon dioxide $\left(\mathrm{CO}_{2}\right)$ (Nelson 1971:306 and Rye 1981:49). An examination of Table III shows a relative range of uniformity among all samples for Fe and $\mathrm{Na}$.

As previously mentioned, co was included because of its occurrence as a colorant in several samples. A brief comparison of the descriptions of samples in Table I to the data in Table II reveals that no apparent relationship exists in the assay as to whether co could be visually identified and if so, whether or not it was mechanically removed. of the remaining elements in Table III, Th is the only element identified which clearly distinguishes the stonewares of the Buena Vista Pottery Company from those of the Palouse Pottery Company in the samples (see Table I). On this premise, Th was used as the ordinate 


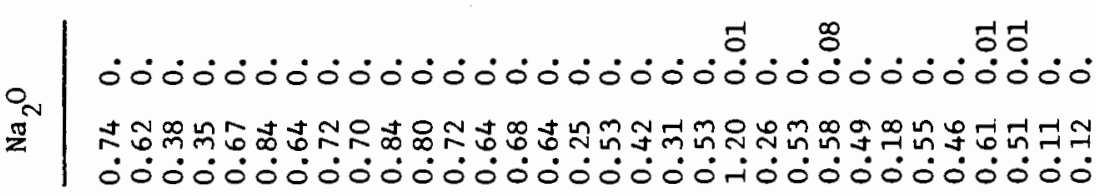
88 \& 888888.888888088 9.88:88

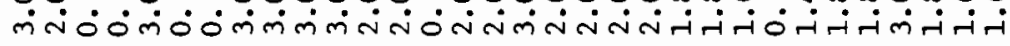
৪8 \& 888888 8888요요 유요요

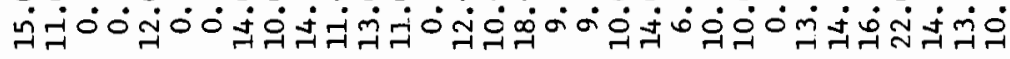

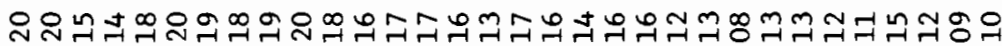
00000000000000000000000000000000

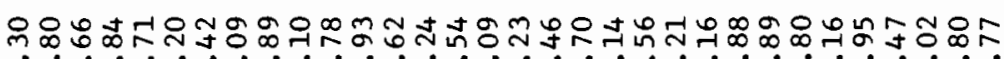

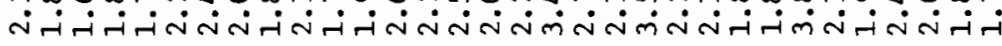

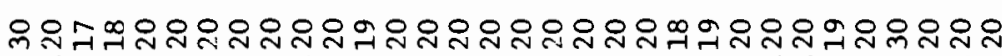

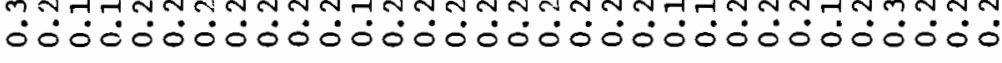

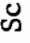

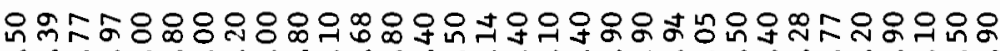
ơ

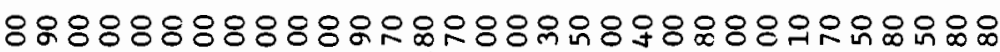

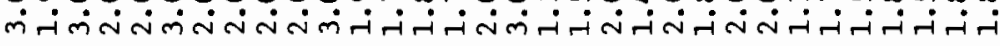

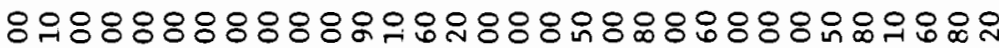

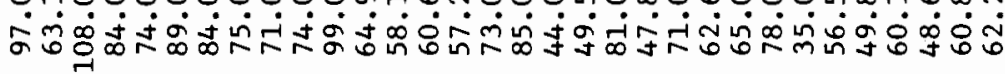

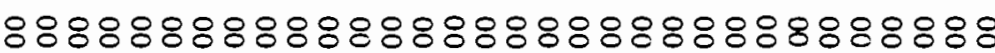

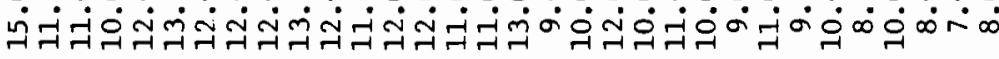

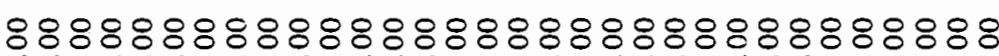
ठ

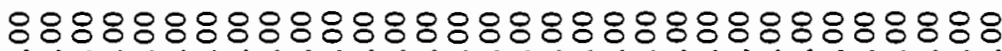

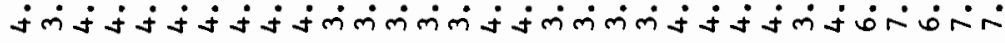

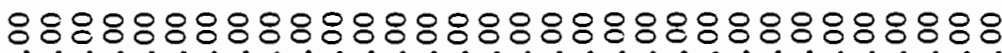

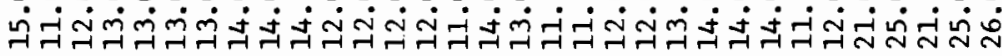

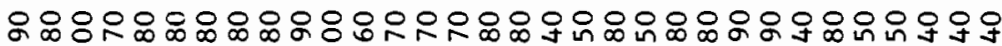

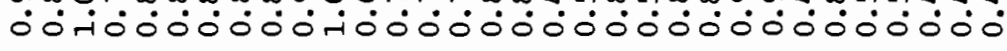

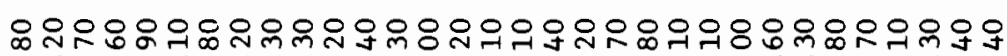

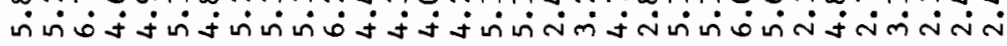

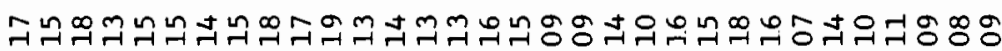

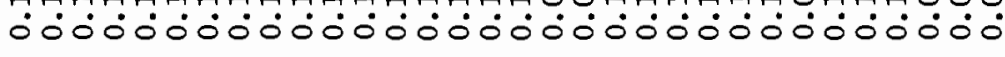

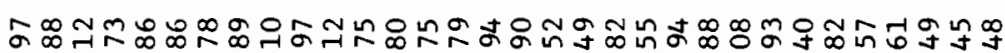

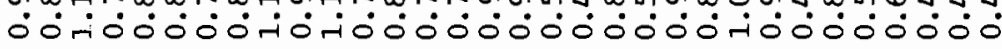

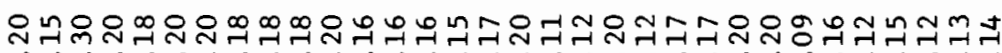

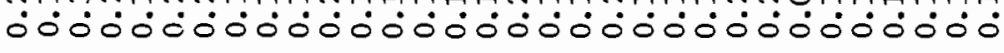

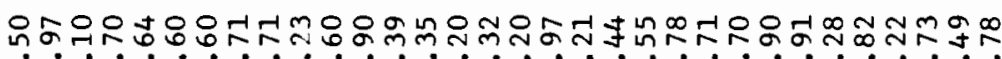

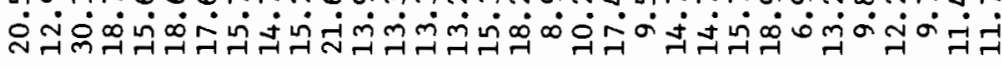

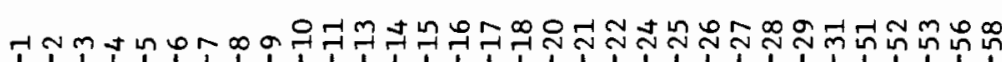

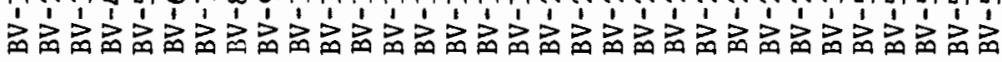

苛 5웡 कृ is is

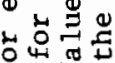
$4{ }^{4}>$ 范范节 E导号 웡 跑至 计늘 도ㅇㅝㅕ 車= Q 吉这急 。员氙. is

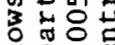
2.: 운다응 o 0 边出 些的为需 可嵒寻 ป $\stackrel{\pi}{\pi} \rightarrow 0^{0}$ मे त्रा

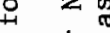

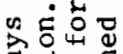
त्र

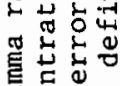
車苟 菏真 웅효

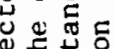
正的. क ष og

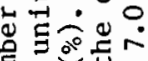
言步范要

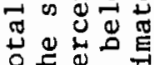

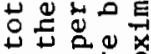

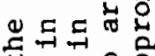

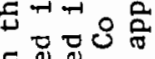

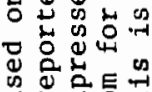

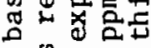

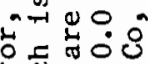

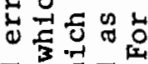
몽

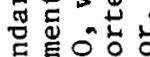
ฮี 出要要过 
for a number of trial bivariate plots against other selected elements. Ratios of inferential merit were determined to be those of Th with ytterbium ( $\mathrm{Yb}$ ) and Th with $\mathrm{Cr}$. These ratios are presented in Figure 1 $(\mathrm{Th} / \mathrm{Yb})$ and Figure $2(\mathrm{Th} / \mathrm{Cr})$. 


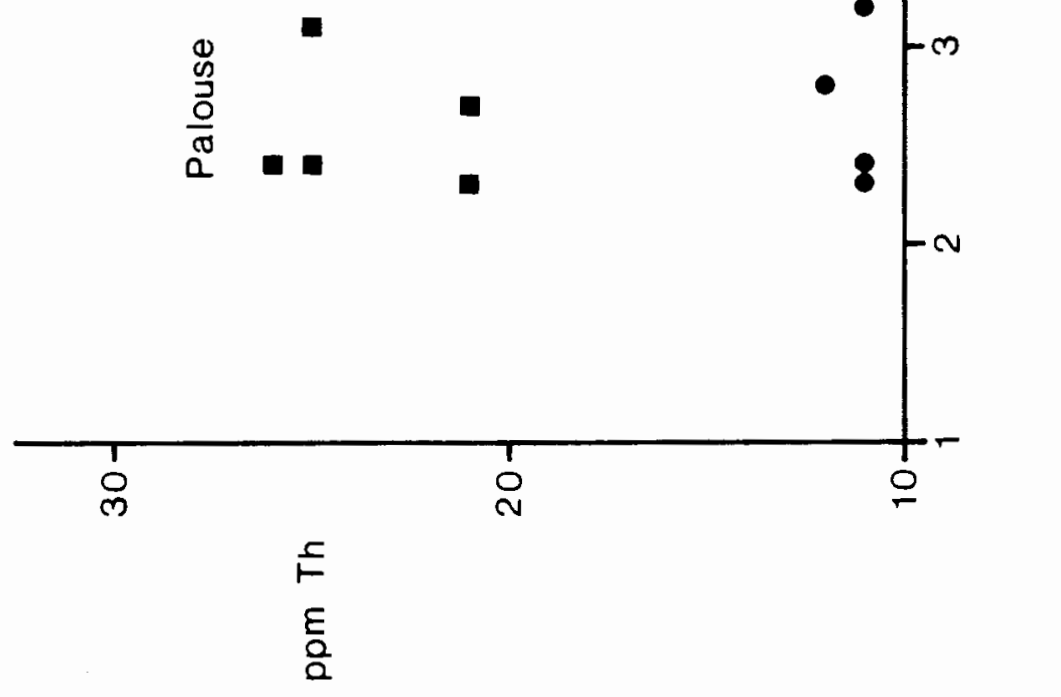




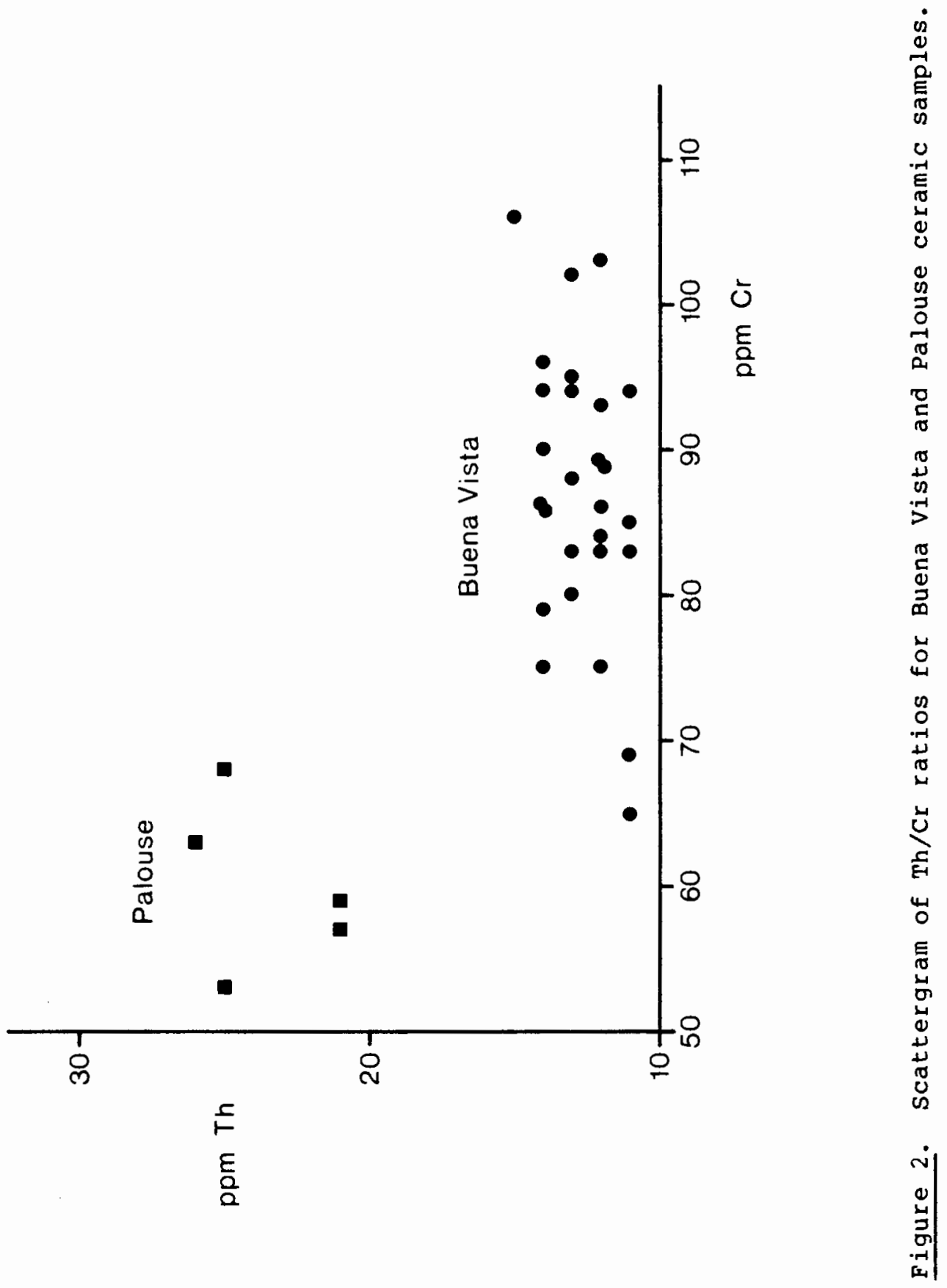


CHAPTER IV

DISCUSSION

Th/Yb AND Th/Cr RATIOS

Inferential chemical signatures for Buena Vista ceramics are reported in the $\mathrm{Th} / \mathrm{Yb}$ and $\mathrm{Th} / \mathrm{Cr}$ ratios (Figures 1 and 2 ) for two reasons: (1) They best illustrate a clear demarcation between the Palouse control group and the Buena Vista samples compared to all other ratios of selected elements and, (2) they confirm along with technological support a subgroup within the Buena Vista cluster itself.

In review of Table $I$, it will be seen that sample numbers $B V-20$, BV-21, and BV-24 consist of black and brown glazed covers with impressed floral motifs. For Buena Vista ceramics, these three samples appear distinctively to the left of the cluster in their Th/Yb ratios (Figure 1) and are represented by the three plots in the lower left of their Th/Cr ratios (Figure 2). Although, as will be discussed, consideration was given to other variables which might contribute to the generation of subgroups within the Buena vista cluster, this subgroup is distinguished primarily by impressed floral motifs.

\section{CHEMICAL VARIABILITY}

Several explanations can be given for possible variability in the chemistry of clays and glazes used in the manufacture of ceramics. 
These include different temper-to-clay ratios, incomplete mixing, uneven distribution of minerals such as large inclusions of one or more minerals, and firing temperature relative to volatilization and combustion of certain elements. Also, variations in clay sources, such as from flood plains or agricultural land, which may vary annually can influence chemical signatures in the products of a pottery (Rye 1981:47$49)$.

Some samples in this study were specifically prepared to determine if glaze chemistry would significantly skew the results of analysis. The following groups are inclusive of samples taken from the same sherd with, or without, glaze removed and reported as prepared: (1) BV-l, no glaze; BV-6, salt glaze; BV-7, Albany glaze; (2) BV-5, no glaze; BV-8, salt and Albany glaze; (3) BV-17, salt and Albany glaze; BV-25, Albany glaze; (4) BV-18, Albany glaze; BV-22, Albany glaze; (5) BV-20, Albany glaze; BV-24, Albany glaze; (6) BV-51, Albany and salt glaze with cobalt underglaze motif; BV-52, salt glaze with cobalt underglaze motif; BV-53, Albany glaze and cobalt underglaze motif; (7) BV-56, salt and Albany glaze; BV-58, Albany glaze (see Table I).

Assessment of the data as reported in the $T h / Y b$ and $T h / C r$ ratios (Figures 1 and 2 ) and in the range of variation for all selected elements as presented in Figure 3 suggests that glaze chemistry had no significant effect on the concentrations of elements in samples of the above groups or on the analysis as a whole. Although glaze chemistry may contribute to the overall picture of chemical variability among samples in this study, variables previously mentioned must be given the 
weight of consideration. At present it is not possible to attribute any causality in this arena of chemical variability. 


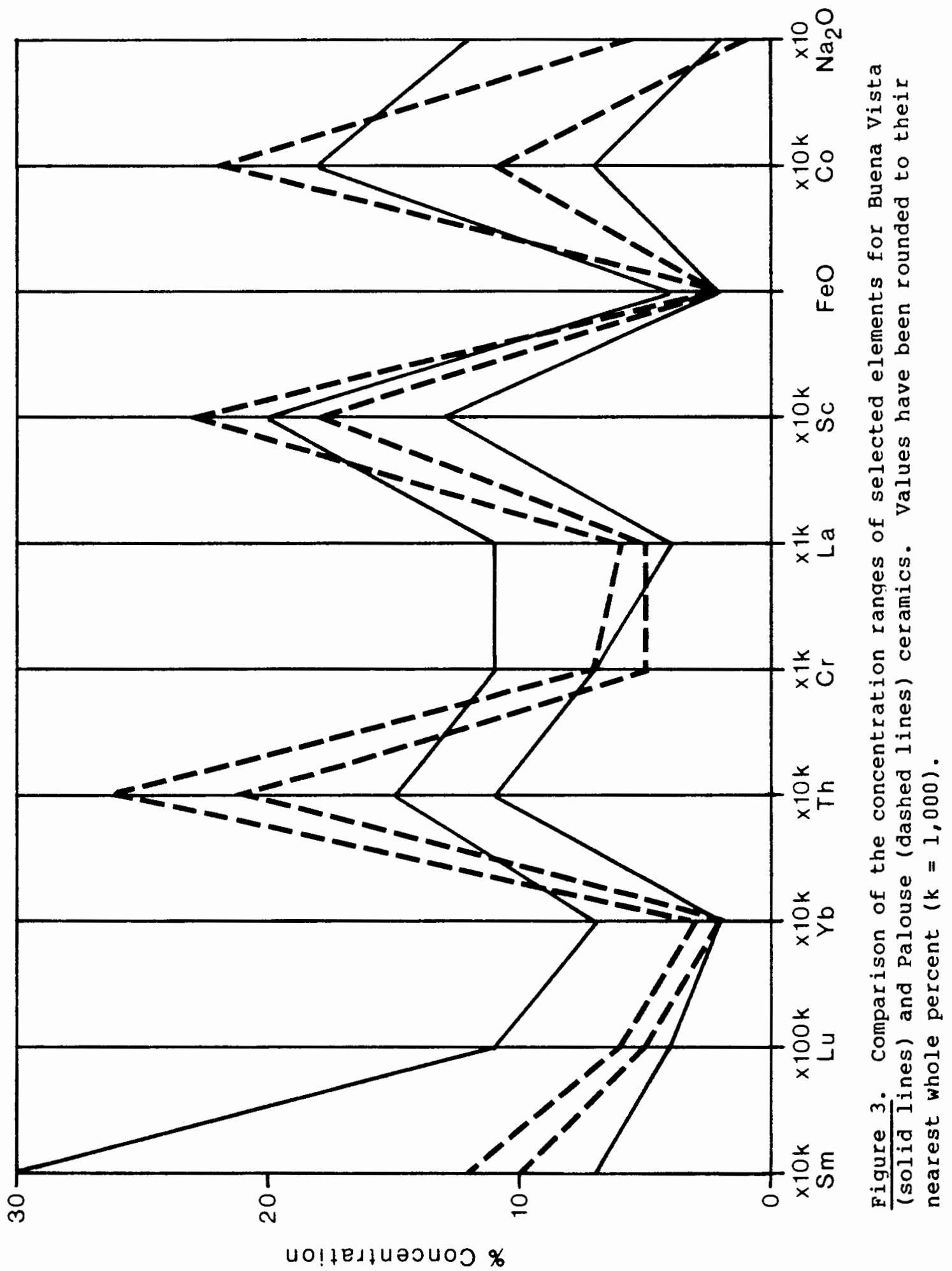


CHAPTER V

CONCLUSIONS

The $\mathrm{Th} / \mathrm{Yb}$ and $\mathrm{Th} / \mathrm{Cr}$ ratios in the samples tested demonstrate significant chemical signatures for the identification of Buena Vista ceramics. This conformity among samples serves further to validate the typological and processual schemata arrived at by scheans (1984) with regard to a manufacturing provenience and its implied clay source(s).

With the possible exception of the floral impressed covers discussed in the previous chapter, variations in style and technology do not appear at this time to be a result of intrusive ceramics. Rather, this variation is most likely representative of historical development and/or idiosyncratic production.

Scheans (1984:4) has suggested that the floral impressed covers may be intrusive. If this is the case, these covers were probably manufactured using a clay source(s) located very near that used by the Buena Vista Pottery Company. The chemical subgroup of the cover samples is not that far removed from the Buena vista cluster as a whole and is certainly within the range of variation found in the bivariate plots of other Buena Vista samples in their $\mathrm{Th} / \mathrm{Yb}$ and $\mathrm{Th} / \mathrm{Cr}$ ratios (see Figures 1 and 2). Possibilities which might explain the position of this subgroup, yet remain consistent with a singular manufacturing provenience, include different temper-to-clay ratios, perhaps for 
increased durability, and historical accident, as in the use of clays from active floodplains or agricultural lands nearby.

The chemistry of salt and Albany slip glazes as well as cobalt underglazes used on Buena Vista and Palouse samples appears to have had little or no effect on the overall analysis of ceramics in this study. Considering the statistical limitations set by the number of samples of Buena Vista and Palouse ceramics, the ranges of variation in the $\mathrm{Th} / \mathrm{Yb}$ and $\mathrm{Th} / \mathrm{Cr}$ ratios appear to be relatively small in each group respectively. Even so, the ranges of variation are large enough in the case of the Buena Vista samples to prompt inquiry beyond the scope of this study. Methodologies for ceramic compositional analysis should not be limited to those used for chemical analyses alone. valuable supplemental data is available from petrographic analysis supported by a knowledge of regional geology. Compositional analyses of ceramics are obviously interdisciplinary pursuits requiring specialized knowledge and ideally a collaborative effort in geology, mineralogy, and chemistry for archaeological interpretation (see Bishop, Rands, and Holley 1982). Reeping the latter in mind, further research may help to explain the ranges of chemical variation determined in this study. Further research objectives for the study of Buena vista ceramic chemistry should include, but not be limited to, clay sourcing, comparative studies of regional ceramics, and the examination of probable trade networks. As more data are compiled, it may become possible to isolate chemical subgroups attributable to formal identification and, with the benefit of archaeological inference, dating for historical and anthropological interpretations. 
REFERENCES CITED

Attas, M., Yaffe, L, and Fossey, J. M. 1977. Neutron Activation Analysis of Early Bronze Age Pottery from Lake Vouliagméni, Perakhóra, Central Greece. Archaeometry, 19(1):33-44.

Beeson, Marvin H. 1986. Personal communication.

Beeson, Marvine H. and Reedy, Curtis R. 1968. Unpublished manuscript.

Bishop, Ronald L., Rands, Robert L., and Holley, George R. 1982. Ceramic Compositional Analys is and Archaeological Perspective. Advances in Archaeological Method and Theory, Volume 5. New York: Academic Press.

Filby, R. H., et al. 1970 Gamma Ray Energry Tables for Neutron Activation Analysis. pullman: Nuclear Radiation Center, Washington State University.

Flanagan, F. J., ed. 1976. Description and Analysis of Eight New USGS Rock Standards: USGS Professional Paper, 840.

McMillan, David J. 1978. Neutron Activation Analysis with Multiplet Deconvolution. Tracor Northern, Inc.

Nelson, Glenn C. 1971. Ceramics: A Potter's Handbook. New York: Holt, Rinehart, and Winston.

Rye, Owen S. 1981. Pottery Technology: Principles and Reconstruction. Washington: Taraxacum.

Scheans, Daniel J. 1984. Buena Vista Stonewares: A Nineteenth Century Oregon Pottery. Northwest Anthropological Research Notes, $18(1): 34-53$. 


\section{APPENDI $X$}

\section{FORTRAN PROGRAM FOR INAA}

\section{FESII-LIE / GEOCHEM/INAA7}

00100 00200 $0030 \mathrm{~L}$

$0040 \mathrm{C}$

$0050 \mathrm{C}$

$0060 \mathrm{C}$

0070

$0080 \mathrm{C}$

$0090 \mathrm{C}$

$0100 \mathrm{C}$

$0110 \mathrm{C}$

$0115 \mathrm{C}$

$0120 \mathrm{C}$

$0130 \mathrm{C}$

$0140 \mathrm{C}$

$0150 \mathrm{C}$

01600

$0170 \mathrm{C}$

$18 \%$

$0190 \mathrm{C}$

$0200 \mathrm{C}$

i. 100

$0 ? 200$

$0230 \mathrm{C}$

02400

02500

$0260 \mathrm{C}$

$0270 \mathrm{C}$

02800

02900

03000

03100

03200

$0330 \mathrm{C}$

$0340 \mathrm{C}$

$0350 \mathrm{C}$

$0360 \mathrm{C}$

$03 \% 00$

03800

0790

04001

$0410 t$

$040 \mathrm{r}$

0430

04400

0450

0460

04700

04801

04900

05000

o다의

0500

05300

0540

0550

0560

0570

0580

0590

0600

0610

0620

THIS PFOGRAM REIUCES INSTFUMENTAL NEUTRON ACTIUATION ANALYSTS UATA TO ELEMENT ABUNIIANCES HY COMFARING SAMFLES TO A KNOWN CONCENTRATIOH IN A STANLIALI. IT ALSO COMFIJTES RELATIVE EFHOF'S EASEL ON COLINTING STATISTIOS. FFOGRAMMET: MAFUIN H EEESON - CLETIS F' KEEEIY, REEII COLLLEGE, 1968 MOLIFIEII: ANSEL G JOHNSON - MICHAEL R MOFAN, FOFTLANII SIATE IJNIU. AIHG 1075 MOLIFIEL: MICHAEL R MURAN, FORTLANI STATE UNIU, FEB 19\%

PROGFAH IS IN O29 FUNCH COLE

EXFLANATION

FOERAT

FIRST IIATA CAFII

NUMBEF OF SFECTRA IIETECTELI

IJ NUMEER OF FEAKS FEF SFECTFA

NE. NUMHER OF ELEMENTS PEF SFECTFA

NS NUMHEF OF SFECTRA TO BE EXCLUIIEI FROM SIJMMAFY TAHLE

EXFIII EXFERIMENT IIIENTIF ICATION

SECONL IIATA GFOUF - STANLIAFI AND SAMFLE INFGRMATION (LINE. S1.) 2 IIATA GFIUUF'S FER CAFII

NAME 1 J.ST HALF STANIIAFII OF SAMFLE ILIENTIFICATION

NAME2 2NI HALF STANIIAFII OF SAMFLE ITIENTIF ICATLON

*************

WT WF TGHT OF SAMFLE OF STANDIARL

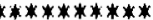

CTIII TIME IN IIAYS TO START OF COUNTING AFTER IFEAIIIATION ************

LITM1 TIETECTION TIME IN SECONIIS

$* * * * * * * * * * *$

THIFI TATA CARD GFOUH - ELEMENT INFOFMATION ILINE S5)

1 IIATA GROUF FEF CART

NMFK EIERENT LETECTED, FEAK NAME

***********

ISTI LDCATION OF STANIAAEI AMUNG ORDERELI SAMFLES ANI STANTAFITS

**************

CONC EIEMENT CUNCENTRATION IN STANLAFL

************

HLF HALF-LIFE. IN IIAYS, OF JSOTOFE BEING [IETECTEI

***********

WNTTS URTTS OF MEASUFE FOF STANIARD

***********

NUMER OF ELEMENT FEAKS IO RE AUEFAGEI TN SUMMARY TARLE

A4

A4

$2 x$

6.4

$1 x$

$F 1.0 .6$

$1 x$

$F ?+9$

$1 \times$

FOUFTH IIATA CAFI GHOUF (LINE 5?)

J IIATA GROUF'S FER CAEI

NLL1 NET COIJNTS T.N FEAK

************1\%

EFIF NHT EREOEF FOR EACH FEAK

$+8 \cdot 0$

$1 \times$

$F 4,1,1 x$

FEAL NAME 1 (45), NAME2 ( 45 ), NMFK $(30)$, L.AM , NG, NC 1 (45)

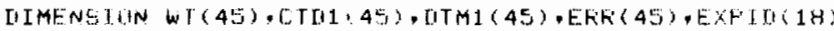

DIMENSTON FFM $(30,45)$, REt $(30,45)$. FFML $(20,45), F E L 1(20,45)$, MF $(30$

REA[1 22,101$) \mathrm{TI}, J]$,NE, NS, (EXF $1[(K), K=1,18$ )

101 FOFHAT (4I2, 18A4)

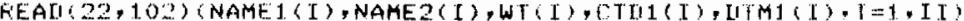

102 FORMAT $(2(2 A 4,2 X, F 6,4,1 X, F 10,0,1 \times, F, 0,1 X)$

III 2 I $1=1, \mathrm{~J}$

$t=1$ 


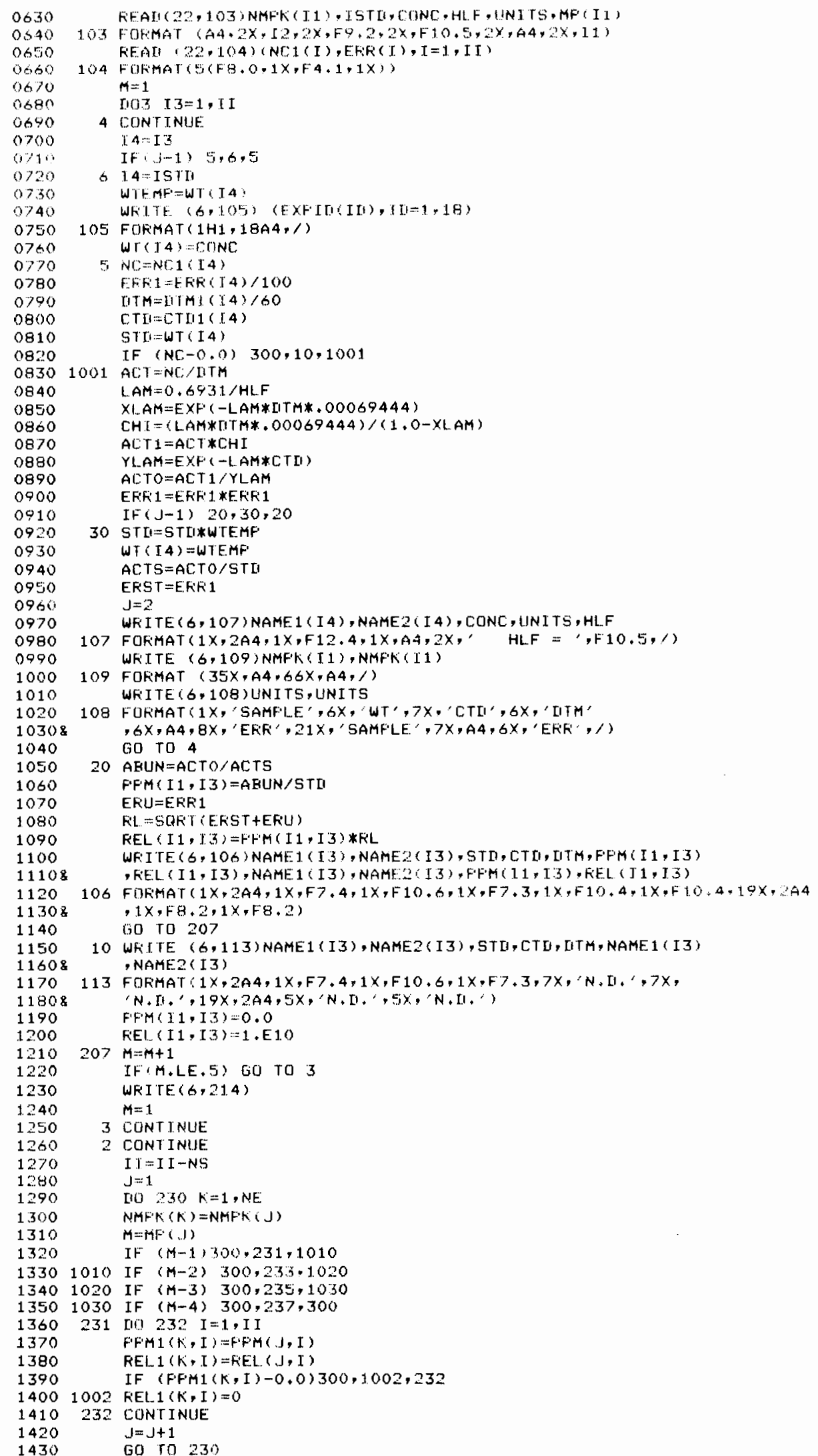




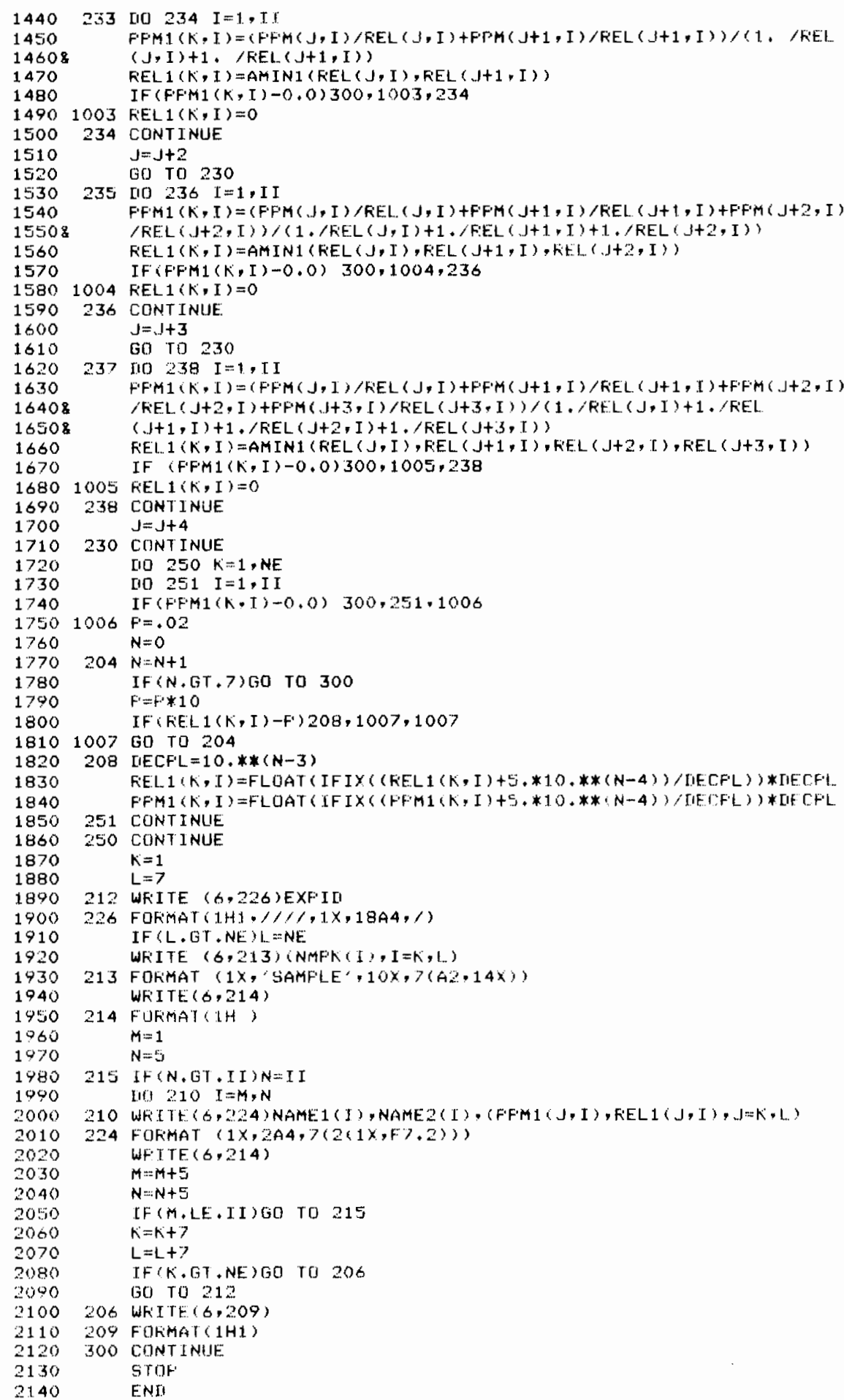

